\title{
Medical devices that look like medicines: safety and regulatory concerns for children in Europe
}

\author{
Suzy Huijghebaert, ${ }^{1}$ Pauline De Bruyne, ${ }^{2,3}$ Karel Allegaert, ${ }^{4,5}$ Saskia Vande Velde, ${ }^{2}$ \\ Ruth DeBruyne, ${ }^{2}$ Stephanie Van Biervliet, ${ }^{2}$ Myriam Van Winckel ${ }^{2}$
}

\begin{abstract}
1Pharmacist, Brussels, Belgium
${ }^{2}$ Department of Paediatric Gastroenteroloy, Ghent University Hospital - Ghent University, Gent, Belgium ${ }^{3}$ Department of Paediatric Gastroenterology, Erasmus MC, Rotterdam, The Netherlands ${ }^{4}$ Department of Paediatrics, Division of Neonatology, Sophia Children's Hospital, Erasmus MC, Rotterdam, The Netherlands ${ }^{5}$ Department of Development and Regeneration, KU Leuven, Leuven, Belgium
\end{abstract}

\section{Correspondence to}

Dr Myriam Van Winckel,

Paediatric gastroenterology, Ghent University Hospital 3K12D, Gent 9000, Belgium; myriam.vanwinckel@ugent.be

Received 14 October 2018 Revised 28 July 2019 Accepted 23 August 2019

\section{Linked}

- http://dx.doi.org/10.1136/ archdischild-2018-316385

Check for updates

(c) Author(s) (or their employer(s)) 2019. No commercial re-use. See rights and permissions. Published by BMJ.

To cite: Huijghebaert S, De Bruyne P, Allegaert K, et al. Arch Dis Child Epub ahead of print: [please include Day Month Year]. doi:10.1136/ archdischild-2018-316391

\section{ABSTRACT}

Medical devices (MedDevs) and medicines are assessed (and monitored) differently before and after launch. There are products for repeated oral ingestion that are marketed in the European Union as MedDevs.

Objectives and methods To illustrate the consequences of these differences in assessment, we compared the leaflet information of three MedDevs with the standards for medicines and with published evidence at launch. As examples, gelatin tannate (GT), its combination with tyndalised probiotics (TP) (GTTP) for diarrhoea and a gel containing hyaluronic acid (HA)/ chondroitin sulfate (CS)/poloxamer (Pol407) (HACSPol) for gastro-oesophageal reflux disease were examined. Results Applying standards for medicines, product composition is insufficiently defined in the MedDev leaflet (eg, plant origin, polymerisation grade, dose and ratio of the relevant constituents). All leaflets allow unlimited use in children from birth onwards, while published clinical documentation in children was poor (GT) or lacking (GTTP and HACSPol). MedDev leaflets do not mention adverse events (AEs), while literature search suggests safety concerns such as tannic acid (TA) cytotoxicity, potentially more diarrhoea/AEs with TP, use of doses higher than established safe (TA and HA) and lack of chronic toxicity studies for oral Pol407. None refers to interactions with medicines, although some ingredients may affect medicine absorption.

Conclusion Although these MedDevs require repeated oral intake as do medicines, their assessment and monitoring differ significantly from the standards for medicines. Compared with medicines, MedDevs for repeated oral use are poorly labelled and rely on very limited clinical information at market release.

\section{INTRODUCTION}

The term 'Medical device (MedDev)' covers a wide array of products for medicinal use, from wound dressings, surgical instruments to implants. European regulation defines a MedDev as 'any instrument... material or article intended by the manufacturer to be used, alone or in combination, for human beings for one or more of the following medical purposes: ... prevention... treatment or alleviation of disease... modification of anatomy or of a physiological or pathological process... AND does not achieve its principal intended action by pharmacological, immunological, or metabolic means in or on the human body, but which may be assisted in its function by such means. ${ }^{1}$ MedDevs are classified according to their intended purpose and inherent risks (classes I, IIa, IIb and III). ${ }^{1}$

\section{What is already known on this topic?}

- Marketing of medical devices (MedDevs) is regulated differently from marketing of medicines.

- Current legislation resulted in the marketing of MedDev perceived as if it were medicines, without review by the European Medicines Agency or competent national medicinal authorities.

\section{What this study adds?}

- Using an illustrative approach, leaflet content of orally ingested MedDevs is shown not to attain the quality of leaflets for medicines.

- Efficacy and safety in children are not granted at launch of these MedDevs: randomised placebo-controlled trials to document efficacy and safety in children were limited, since either initiated after launch (gelatin tannate (GT)) or even still lacking (GT and its combination with tyndalised probiotics and hyaluronic acid/ chondroitin sulfate/poloxamer).

- Based on this illustrative approach, we highly recommend that MedDev regulation needs further revision, reconsidering MedDevs for repeated oral intake and including the needs of children.

MedDevs are regulated in the European Union (EU) by the Directorate-General for Internal Market, Industry, Entrepreneurship and small and medium enterprises (Grow), requiring local notification of 'CE-certified' products. ${ }^{2}{ }^{3}$ The digits following a CE mark identify the notifying body, an EU-accredited private company contracted and paid by the manufacturer or marketing company to supply certification to enter the market. A CE mark without digits indicates the company has self-marked/self-certified the product. ${ }^{4}$ While the US Food and Drug Administration (FDA) requires evidence of safety and efficacy of MedDevs, premarket evaluation of MedDevs in the EU only requires safety justification, and eventually 'performance' demonstration. ${ }^{5}{ }^{6}$ Pharmacokinetic, pharmacodynamic and efficacy studies are not required for MedDevs. ${ }^{5}{ }^{6}$ Following certification, MedDevs enter the EU as over-the-counter (OTC) products in (drug)stores and pharmacies through free movement of goods by CE marking. There is no claim 
Table 1 Comparison of definition, regulatory requirements for market entry and postlaunch conditions of medical devices (MedDevs) and medicinal products, including relevant paediatric aspects, in the European Union (EU)

\begin{tabular}{|c|c|c|}
\hline & MedDevs* & Medicinal drugs/medicines \\
\hline Definition & $\begin{array}{l}\text { Any instrument,... material or other article intended by the manufacturer to be used, alone or in } \\
\text { combination, for human beings for one or more of the following medical purposes: ... prevention ... } \\
\text { treatment or alleviation of disease... modification of anatomy or of a physiological or pathological } \\
\text { process or state,... } \\
\text { AND which does not achieve its principal intended action by pharmacological, immunological, or } \\
\text { metabolic means in or on the human body, but which may be assisted in its function by such means. } \\
\text { (Directive } 93 / 42 / E E C \text { and Directive } 2007 / 47 / \text { CE replaced by Regulation (EU) } 2017 / 745 \text { (implementation } \\
2020) \text { ) }\end{array}$ & $\begin{array}{l}\text { 1. Any substance or combination of substances presented } \\
\text { as having properties for treating or preventing disease in } \\
\text { human beings. } \\
\text { 2. Any substance or combination of substances that may } \\
\text { be used in or administered to human beings either with } \\
\text { a view to restoring, correcting or modifying physiological } \\
\text { functions by exerting a pharmacological, immunological or } \\
\text { metabolic action or to making a medical diagnosis. } \\
\text { (Directive } 2001 / 83 / E C \text { ) }\end{array}$ \\
\hline $\begin{array}{l}\text { Requirements for } \\
\text { market entry }\end{array}$ & $\begin{array}{l}\text { Local CE certification by the manufacturer, appointing a notifying body (NB) for higher class } \\
\text { MedDevst. The certification authorises unlimited market access in the EU. } \\
\text { Requirements: labelling must conform to the 'Regulations' and thus to the intended purpose as stated } \\
\text { by the manufacturerł: } \\
\text { Depending on the classification: quality assurance } \pm \text { clinical information(performance/safety } \\
\text { (justification)). } \S \\
\text { New regulations (2017) require higher standards - clinical trials to support safety in the case of } \\
\text { higher risk classes. } \\
\text { Children: if the intended use of the device includes children, information on residual risks and } \\
\text { precautionary measures are required. (No specific paediatric regulation). } 1 \text { ** } \\
\text { Certification by manufacturer/NB. } † \\
\text { (Directive } 93 / 42 / E E C \text { and Directive } 2007 / 47 / C E \text { replaced by Regulation (EU) } 2017 / 745 \text { (to implement } \\
\text { in 2020)) }\end{array}$ & $\begin{array}{l}\text { Registration, following evaluation by European Medicines } \\
\text { Agency or via mutual recognition (if initial national } \\
\text { registration). } \\
\text { Requirements: } \\
\text { Full registration file including (clinical) pharmacology, } \\
\text { toxicology, pharmacokinetics, clinical efficacy and safety } \\
\text { (well-controlled randomised clinical trial). } \\
\text { Labelling in line with registration file under control of } \\
\text { EMA/medicinal authority. } \\
\text { Stringent paediatric regulation: requiring an agreed } \\
\text { paediatric investigation plan. } \\
\text { Approval by an independent (centralised or national) } \\
\text { medicinal authority. } \\
\text { (Regulation (EC) No 726/2004 } \\
\text { Regulation (EC) No 1901/2006 and Regulation (EC) No } \\
\text { 1902/2006) }\end{array}$ \\
\hline Marketing & $\begin{array}{l}\text { Direct release over the counter (OTC). } \\
\text { Direct to consumer advertising allowed. } \\
\text { No claim control - objections to be addressed to Ministry of Economics. }\end{array}$ & $\begin{array}{l}\text { OTC strictly limited: requiring specific OTC registration. } \\
\text { Direct-to-consumer advertising limited to OTC products. } \\
\text { Strict claim control by medicinal authorities. }\end{array}$ \\
\hline $\begin{array}{l}\text { Vigilance and market } \\
\text { surveillance }\end{array}$ & $\begin{array}{l}\text { Postlaunch health technology (risk) assessment by manufacturer. } \\
\text { Since breast implant scandalף: } \\
\text { 2014: materiovigilance for implantable MedDevs - competent authorities request the reporting of } \\
\text { 'serious events'. } \\
\text { >2020: enforcement of coordination between Member States in the fields of vigilance and market } \\
\text { surveillance (EUDAMED2). } \\
\text { (Regulation (EU) No } 920 / 2013 \text { \& Regulation (EU) } 2017 / 745 \text { ) }\end{array}$ & $\begin{array}{l}\text { Structured pharmacovigilance, safety monitoring - all adverse } \\
\text { events. } \\
\text { (Directive 2010/84/EU - Regulation (EU) No 1235/2010) }\end{array}$ \\
\hline
\end{tabular}

References refer to their main EU regulations.

*Confusing semantics with regard to medicines across the EU: in Germany, 'Medizinprodukte' (literally translated to medicine products) resort under MedDevs (https://www. bundesgesundheitsministerium.de/).

TA notified body is an organisation designated by an EU country to assess the conformity of certain products before being placed on the market. These bodies carry out tasks related to conformity assessment procedures set out in the applicable legislation, in the case a third party is required.

fln the file, it must be shown that the product conforms to the intended purpose (meaning the use for which the device is intended according to the data supplied by the manufacturer on the labelling in the instructions and/or in promotional materials).

$\S^{\prime}$ Clinical data' in the EU means safety and/or performance information. Performance is defined as 'ability of the device to achieve its intended purpose as stated by the manufacturer'. In the USA in contrast, the FDA requires randomised clinical trials demonstrating safety and 'efficacy/effectiveness' for MedDevs. ${ }^{106} 107$

IIIn the MedDev regulations, a 'Poly Implant Prothesis Plan' was initiated after the scandal of defective breast implants, as a joint action to tighten controls, and provide a better guarantee for the safety of implantable MedDevs (Regulation (EU) No 920/2013).

**The regulations do not specify the nature and quality requirements of the information on residual risks and precautionary measures in children, except for the presence of carcinogenic, mutagenic, reprotoxic and/or endocrine-disrupting substances, where justification/argumentation is needed.

t+For MedDevs, there is no approval procedure by independent (centralised) regulatory body; the CE mark affirms simply that the product 'meets high safety, health and environmental protection requirements'. ${ }^{109}$ The notifying body must have at its disposal the necessary personnel, relevant knowledge and experience to carry out the conformity assessment (without further specifications). ${ }^{108}$ In contrast, in the USA MedDevs are subjected to an approval procedure by the FDA, assessing the device's effectiveness as well as its risk of harm (requiring safety, efficacy and device consistency). To that extent, FDA may refer the premarket approval to an outside panel of experts (advisory committee). ${ }^{107} 108$

control, and direct-to-consumer promotion is permitted. In contrast, medicine 'evaluation' requires pharmacokinetic, pharmacodynamic and clinical efficacy studies to enter the EU by the European Medicines Agency (EMA) ${ }^{7}$. Medicines are subjected to strict claim control and are prescription-only at launch. Directto-consumer promotion is only permitted for OTC products and is controlled by the authorities. Table 1 summarises the main differences in definition, regulatory approach and (post) marketing. Particularly for children, this differs significantly from paediatric medicine development. ${ }^{8-11}$

The last part of the MedDev definition ('does not achieve its principal intended action by pharmacological, immunological, or metabolic means in or on the human body, but which may be assisted in its function by such means') leaves room for different interpretations. By claiming a barrier mechanism as principal mode of action (a prerequisite for borderline products to follow the MedDev approach) ${ }^{12}$ products for repeated oral intake with medicinal indication are marketed in the EU as MedDevs. When challenging doctors, pharmacists and patients with such MedDevs, or read press articles, ${ }^{13}$ we believe that these products could be perceived as medicines, likely because of their indication, formulation and repeated mode of administration similar as for a medicinal drug. Van Norman et al, comparing European and US approval processes of medicines and MedDevs pointed to the fact that: Although the CE mark is often mistakenly equated to being a seal of quality... CE marking does not represent quality, even though consumers often assume that products bearing CE marking are of better quality'. ${ }^{5}$ As there is a clear difference between MedDevs and medicines in assessment before and after launch in the EU (table 1), we sought to demonstrate how the information presented for MedDevs intented for repeated ingestion differs from that expected for a medicine, using three MedDevs promoted for gastrointestinal problems as examples.

\section{METHODS}

We compared the leaflet information of three MedDevs with the standards required for medicines. ${ }^{7}$ Leaflets were screened for 
Table 2 Formulation for children of the claimed barrier medical device (MedDev) products

$\begin{array}{lll}\text { GT } & \text { GTTP } & \text { HACSPo } \\ \text { Tasectan } & \text { Tasectan Duo } & \text { Ziverel } \\ \text { Gelenterum } & \text { Gelenterum Duo } & \text { Esoxx }\end{array}$

\begin{tabular}{|c|c|c|c|}
\hline $\begin{array}{l}\text { Ingredients claimed to form } \\
\text { barrier }\end{array}$ & GT & $\begin{array}{l}\text { GT+heat-killed Lactobacillus acidophilus, } \\
\text { L. plantarum, L. casei, L. rhamnosus, } \\
\text { Bifidobacterium bifidum, Streptococcus } \\
\text { thermophiles. }^{1516}\end{array}$ & $\begin{array}{l}\mathrm{HA}+\mathrm{CS} \\
(\mathrm{Pol} 407)\end{array}$ \\
\hline Dispensing form in children & $\begin{array}{l}\text { Sachet with brownish powder to add to liquid } \\
\text { (water, milk...). }\end{array}$ & Sachet to add to some water, milk or fruit juice. & $\begin{array}{l}\text { Sachet with gel to swallow with glass } \\
\text { of water. }\end{array}$ \\
\hline $\begin{array}{l}\text { (Presumed) mg dose per unit } \\
\text { in children } \\
\text { Doses per day }\end{array}$ & $\begin{array}{l}250 \mathrm{mg} \mathrm{GT} / \text { sachet. } \\
1-2 \text { sachets each } 6 \text { hour. }\end{array}$ & $\begin{array}{l}\text { Units/mg dose of TPs not disclosed. } \\
1-2 \text { sachets each } 6 \text { hour. }\end{array}$ & $\begin{array}{l}10 \mathrm{~mL}=12 \mathrm{~g} \text { gel (no doses in leaflet). } \\
\% \text { composition by Norgine*: } \\
\text { HA } 1.24 \%(1488 \mathrm{mg}) \text {. } \\
\text { CS } 3.21 \% \text { (3850 mg). } \\
\text { Pol407 } 2.7 \%(297 \mathrm{mg} \text { ). } \\
4 \times x / \text { day or as instructed by doctor. }\end{array}$ \\
\hline Missing information in leaflet & $\begin{array}{l}\text { Nature of T: TA, propyl gallate, gallotannins, } \\
\text { reticulated protein, (non)-hydrolysable T, wine or } \\
\text { carob tannins? }{ }^{1419-21} \\
\text { T source/quality: USP Pharmacopoeia, Chinese, } \\
\text { Turkish or other galls? } ?^{22-26} \\
\text { G Bloom strength? Affects binding with TA. }{ }^{24} \\
\text { Ratio TA/G? Excess TA used to formulate GT; no } \\
\text { rinsing steps in patent. }\end{array}$ & $\begin{array}{l}\text { Behaviour of TPs on sudden lysis in } \\
\text { digestive tract? } \\
\text { Absence of toxins/by-products on } \\
\text { tyndallisation and lysis in GI tract? } \\
\text { Ratio of TA/G/TPs? } \\
\text { See also GT. }\end{array}$ & $\begin{array}{l}\text { HA MW and polymerisation } \\
\text { grade? } \\
\text { HA source: rooster or bacterial? } \\
\text { Ratio HA/CS/Pol ratio? } \\
\text { Pol407: forms micelles/ hydrogels } \\
\text { and may affect disposition of HA } \\
\text { and CS. }\end{array}$ \\
\hline
\end{tabular}

*Personal communication; the mg dose has been calculated per sachet with Pol407 dose as in the patent application. ${ }^{28}$

CS, chondroiting sulfate; G, gelatine; GI, gastrointestinal; GT, gelatin tannate; HA, hyaluronic acid;Pol, poloxamer; T, tannate/tannin; TA, tannic acid; TPs, tyndalised probiotics.

information on product composition and ingredients, usage/indications, clinical efficacy, interactions, toxicity and (long-term) safety. In addition, this was compared with published evidence on efficacy and safety of the specific MedDev in children at time of launch (appendix for search strategy). We analysed information on gelatin tannate (GT), marketed as Tasectan/Gelenterum in the EU, ${ }^{14}$ and its combination with tyndalised (heat-killed) probiotics (TP) (GTTP), internet available as Tasectan Duo für Kinder (Austria) and Gelenterum Duo (Italy), ${ }^{15} 16$ both promoted to treat diarrhoea, also in children. Furthermore, the hyaluronic acid (HA), chondroitin sulfate (CS) and poloxamer (Pol 407) (HACSPol) combination, launched as Ziverel/Esoxx in Italy, Spain, France, Austria and the Benelux ${ }^{17}$ to treat gastro-oesophageal reflux disease (GORD) was evaluated. SH prepared the initial analysis, which was cross-checked by MVW on the basis of the original leaflets.

\section{RESULTS}

\section{Product composition}

Table 2 lists the ingredients with their characteristics, together with the information not provided, applying quality requirements for medicines. When using this approach, composition and dose are not sufficiently accurately defined for all three products. Tasectan sachets contain $250 \mathrm{mg}$ GT powder, but the exact tannate (type, origin, ratio tannic acid (TA)/gelatin $(G)$ ) is not specified. Publications referring to this MedDev intermix the substance TA (usually per pharmacopoeia from oak galls) with gallic acid, elagitannins, wine/fruit (non-hydrolysable), vegetable and carob tannins ${ }^{18-20}$ and even with propyl gallate (Chemical Abstracts Service number provided by manufacturer). ${ }^{21}$ Tannin chemistry is complex: TA/G ratios and dissociation of GT also depends on the polymerisation grade of $\mathrm{G}$ (Bloom strength). ${ }^{22-24}$ This information is lacking in the leaflet, so the exact TA dose and exposure are unknown. Moreover, pharmacological activities and toxicities of tannins and by-products differ according to their origin (eg, differing between Chinese and Turkish galls). ${ }^{25}$ Tannins also show structure-related specificity, ${ }^{22} 27$ depending on their source. For GTTP, the powder additionally contains TPs (see table 2), but units or mg doses remain undisclosed.

The HACSPol gel leaflet does not disclose HA, CS or Pol407 doses; only a per cent composition was provided by the manufacturer on our request so that daily exposure has been calculated (table 2). ${ }^{28}$ Although the molecular weight (MW) and HA polymerisation grade affect absorption and its pharmacological actions $^{2930}$, these characteristics are not addressed in the leaflet. Pol407 is a surfactant-enhancing viscosity, affecting delivery of drugs, peptides/proteins and particles and is not developed for recurrent oral consumption. ${ }^{3132}$

\section{Efficacy in children}

Table 3 lists the major claims and findings in children, as stated in the MedDev leaflet, including age limit and treatment duration. All leaflets allow unlimited use in children from birth onwards. No well-performed randomised clinical trials to demonstrate efficacy and safety in children could be identified at time of MedDev launch. GT and GTTP claim effective relief of diarrhoea of various origin within 12 hours. ${ }^{14-1633}$ Based on literature search, the only support identified for the 12-hour claim at time of launch were open label observations in two cohorts. First, a cohort of 97 children with acute diarrhoea receiving oral rehydration solution (ORS) $+\mathrm{GT}^{34}$ Their characteristics and outcomes were published 3 years earlier than the findings in the control cohort of 114 children on ORS only. ${ }^{35}$ From a medicine evaluation perspective, these studies had-besides the open cohort design—other limitations (concomitant antibiotics allowed but not documented; diagnostic criteria for diarrhoea and stool rating scales not described; the ORS group having a significantly worse stool frequency at baseline; efficacy based on this parameter at 12 hours only; and no further observations confirming efficacy beyond 12 hours). ${ }^{35}$ A placebo-controlled study in adults at product launch (20 patients/group) did not confirm this 12-hour claim. ${ }^{36}$ Postlaunch studies are of low quality, except for one recent well-randomised, placebo-controlled study showing lack of efficacy of GT in acute 
Table 3 Indications, age limit and treatment duration recommended for use of the medical device (MedDev) in the leaflet versus (in italics) evidence from clinical trials at time of launch and postlaunch for gelatin tannate (GT), GT+tyndalised probiotics (GTTP) and hyaluronic acid, chondroitin sulfate and poloxamer (HACSPol)

\begin{tabular}{|c|c|c|c|}
\hline & $\begin{array}{l}\text { GT } \\
\text { Tasectan } \\
\text { Gelenterum }\end{array}$ & $\begin{array}{l}\text { GTTP } \\
\text { Tasectan Duo } \\
\text { Gelenterum Duo }\end{array}$ & $\begin{array}{l}\text { HACSPol } \\
\text { Ziverel } \\
\text { Esoxx }\end{array}$ \\
\hline $\begin{array}{l}\text { Indication } \\
\text { (leaflet) }\end{array}$ & $\begin{array}{l}\text { Diarrhoea (any) } \\
\text { 'Specially developed to treat diarrhoea of } \\
\text { various aetiology'. }{ }^{14}\end{array}$ & $\begin{array}{l}\text { Diarrhoea (any) } \\
\text { 'Dysbacteriosis of varying origin - } \\
\text { diarrhoea, abdominal distension, } \\
\text { gastroenteritis, antibiotic and } \\
\text { chemotherapy associated'. }{ }^{1516}\end{array}$ & $\begin{array}{l}\text { Gastro-oesophageal reflux. 'Protective } \\
\text { treatment of oesophageal mucosa: facilitates } \\
\text { mucosal repair and relieves symptoms... with } \\
\text { erosive lesions'.17 }\end{array}$ \\
\hline $\begin{array}{l}\text { Age limit } \\
\text { Paediatric studies at launch }\end{array}$ & $\begin{array}{l}\text { Birth onwards. } \\
\text { Cohort study in children }>3 \text { months add-on to } \\
\text { oral rehydration solution } \pm \text { antibiotics. }\end{array}$ & $\begin{array}{l}\text { Birth onwards. } \\
\text { None. } \\
\text { Direct selling internet online. }\end{array}$ & $\begin{array}{l}\text { Birth onwards. } \\
\text { None. } \\
\text { In adults, only } 2 \text { weeks add-on to proton pump } \\
\text { inhibitors (PPIs). }{ }^{34}\end{array}$ \\
\hline $\begin{array}{l}\text { Treatment duration } \\
\text { Treatment duration in paediatric } \\
\text { studies }\end{array}$ & $\begin{array}{l}\text { Unlimited. } \\
\text { At launch: } 12 \text { hours. }^{3435} \\
\text { After launch: } 72 \text { hours. }^{3640} \\
5 \text { days. }{ }^{37}\end{array}$ & $\begin{array}{l}\text { Unlimited. } \\
\text { No studies. }\end{array}$ & $\begin{array}{l}\text { Unlimited. } \\
\text { No paediatric studies. } \\
\text { Add-on in adults: } 2 \text { weeks. }{ }^{49}\end{array}$ \\
\hline $\begin{array}{l}\text { Efficacy } \\
\text { Evidence from clinical studies in } \\
\text { children }\end{array}$ & $\begin{array}{l}\text { All types of diarrhoea. } \\
\text { Works within } 12 \text { hours. } \\
\text { Very low quality evidence. } \\
\text { At launch: } \\
\text { No placebo-controlled data for 12-hour } \\
\text { claim in children. } 35 \\
\text { 12-hour claim unconfirmed in double- } \\
\text { blind study in adults. }{ }^{36} \\
\text { No placebo-controlled data nor any data } \\
\text { beyond } 12 \text { hours in children. }{ }^{35} 35 \\
\text { Postlaunch: } \\
\text { Poor quality study: finds efficacy versus } \\
\text { undisclosed placebo; biased by mix } \\
\text { of acute and antibiotic-associated } \\
\text { diarrhoea. } \\
\text { High-quality study: shows lack of efficacy } \\
\text { in children. }{ }^{37}\end{array}$ & $\begin{array}{l}\text { All types of diarrhoea. } \\
\text { Works within } 12 \text { hours. } \\
\text { No studies. }\end{array}$ & $\begin{array}{l}\text { All types of gastro-oesophageal reflux. } \\
\text { No studies in children. } \\
\text { Low-quality evidence in adults, only add-on to } \\
\text { standard PPI doses. }{ }^{48} 49 \\
\text { No studies comparing with PPI. } \\
\text { No studies with data beyond } 2 \text { weeks. }\end{array}$ \\
\hline
\end{tabular}

gastroenteritis in children. ${ }^{37} \mathrm{~A}$ prior small open Italian study (country of notification), labelled 'prospective' in $2013,{ }^{38}$ was republished in 2017 as 'single-blind study' with discrepant results. ${ }^{19}$ Moreover, the protocol was registered post-trial in 2014 (clinicaltrials.gov). ${ }^{39}$ Baseline patient and stool features were poorly characterised. A more recent Turkish placebo-controlled study on GT, claiming efficacy, mixed antibiotic-associated and infectious diarrhoea. ${ }^{40}$ Placebo composition, baseline characteristics per treatment group and primary efficacy parameters were not disclosed. Unusual in acute gastroenteritis, 80\% of the children still vomited 36 hours after starting ORS + placebo, while the proportion with fever was different between text $(65 \%)$ and figure $(12 \%))^{40}$

For GTTP (also notified in Italy), no proof was found in the literature for the claimed 'normalisation of dysbacteriosis', associated with relief of diarrhoea in inflammatory bowel conditions according to the leaflet. Killed TP strains may have immunomodulatory effects by the release bacteriocins and anti-inflammatory agents ${ }^{41-43}$ and hence do not necessarily act as a barrier. Some TPs have been associated with increased diarrhoea and gastrointestinal symptoms in critically ill patients and in healthy newborns; an international panel assessing the safety of probiotics for human use concludes that 'Products comprising heatkilled microbes should not be made available to infants until any adverse effects (AEs) from such products are better understood'. ${ }^{44}$ References to clinical trials with GTTP were not found. Two references recommending GTTP for chronic diarrhoea did not disclose studies with GTTP and at best referred to a review with Saccharomyces boulardii, not present in GTTP. ${ }^{45-47}$
HACSPol is promoted for mucosal repair and relief of GORD symptoms. ${ }^{17}$ Clinical documentation is poor and limited to adults treated for 2 weeks add-on to proton pump inhibitors (PPIs), mixing naïve and PPI-resistant patients, with Vaseline oil in water as placebo. ${ }^{49}$ There are no data comparing HACSPol with PPIs or the single ingredients (justifying the combination), nor data on use beyond 2 weeks. The company was contacted but has not provided data in children, except for the information that 'one child' was included in the clinical trial mentioned earlier. $^{48}$

\section{Safety, with focus on children}

Table 4 summarises the safety information with regard to AEs, toxicity, overdose and interactions, as retrieved from published evidence. The assessed MedDev leaflets do not mention AEs nor overdose instructions. ${ }^{14-17}$ Experience in clinical trials was limited, both with regard to length of treatment and absolute number of subjects treated or even lacking in children at time of launch.

No active monitoring surveillance studies were retrieved, although safety concerns regarding several ingredients can be raised (table 4). Hydrolysable tannates have a complex metabolic fate, as they are hydrolysed, bacterially fermented and absorbed. $^{22} 34$ Tannates (ng/mL- $\mu \mathrm{M}$ range) inhibit the sodium-glucose transporter, digestive and other enzymes ${ }^{50-53}$ depress the immune response ${ }^{545}$ have been associated with hepatoxicity $^{56}$ and display cytotoxicity ${ }^{57}$ also in human enterocytes. ${ }^{58}$ They are not classifiable as safe with regard to carcinogenicity in 
Table 4 Adverse events, safety concerns and potential medical devices (MedDev)-drug interactions for gelatin tannate (GT), GT+tyndalised probiotics (GTTP) and hyaluronic acid, chondroitin sulfate and poloxamer (HACSPol)

\begin{tabular}{|c|c|c|c|}
\hline & $\begin{array}{l}\text { GT } \\
\text { Tasectan and Gelenterum }\end{array}$ & $\begin{array}{l}\text { GTTP } \\
\text { Tasectan Duo and Gelenterum Duo }\end{array}$ & $\begin{array}{l}\text { HACSPol } \\
\text { Ziverel and Esoxx }\end{array}$ \\
\hline $\begin{array}{l}\text { Adverse events (AEs) (leaflet) } \\
\text { Exposure of children in studies at launch } \\
\text { (N treated) } \\
\text { Surveillance studies monitoring AEs in } \\
\text { children } \\
\text { Current postlaunch exposure in published } \\
\text { studies }\end{array}$ & $\begin{array}{l}\text { Not mentioned. } \\
\mathrm{n}=97 \text { for } 12 \text { hours: 'No GT-related AE'; AEs not } \\
\text { listed by cohort (only } 12 \text {-hour observations). } \\
\text { No actively monitored surveillance studies } \\
\text { (direct over the counter (OTC) and no prescription } \\
\text { control). } \\
\text { Postmarketing to-date: } n=167 \\
\quad \text { 2015: } 1 / 31 \text { nausea on } G T^{19} \\
\text { 2017: } n \text { AE observed in } 103 \text { Turkish children } \\
\text { with various type of diarrhoea. } \\
\text { 2018: } 10 \% \text { on GT versus } 15 \% \text { on placebo; GT: } \\
\text { 1/33 abdominal pain, none on placebo. }{ }^{37}\end{array}$ & $\begin{array}{l}\text { Not mentioned. } \\
\mathrm{n}=0 \text { : references referring to other products. } \\
\text { No actively monitored surveillance studies } \\
\text { (direct OTC and no prescription control). } \\
n=0 \text {. }\end{array}$ & $\begin{array}{l}\text { 'No known side effects'. } \\
n=0 ; n=76 \text { adults with trend to more gastrointestinal AEs } \\
\text { on HACSPol ( } 17.7 \% \text { vs } 9.9 \% \text { on placebo). }{ }^{49} \\
\text { No actively monitored surveillance studies } \\
\text { (direct OTC and no prescription control). } \\
n=0 \text {. }\end{array}$ \\
\hline $\begin{array}{l}\text { Safety concerns } \\
\text { (indicating need for studies) }\end{array}$ & $\begin{array}{l}\text { Not mentioned. } \\
\text { Tannic acid (TA) (in ng/mL and } \mu M \text { range) } \\
\text { inhibits sodium-glucose transporter, } \\
\text { many digestive enzymes and precipitates } \\
\text { immunoglobulins. } \\
{ }^{50-55} \\
\text { Metabolism of TA unknown (hydrolysis to } \\
\text { gallic acid GA)?). }{ }^{23} \\
\text { Cytotoxic and not classifiable as safe for } \\
\text { carcinogenecity. }^{57-61}\end{array}$ & $\begin{array}{l}\text { Not mentioned. } \\
-\quad \text { Potential release of toxins during } \\
\text { tyndalisation of probiotics. }{ }^{76} \\
\text { Heat-killed Lactobacillus rhamnosus } \\
\text { increased Gl symptoms and diarrhoea. }{ }^{44}\end{array}$ & $\begin{array}{l}\text { Not mentioned. } \\
\text { Intake of HA } \sim 500 \mathrm{mg} / \text { day }>\text { food suppl (50-100 mg/ } \\
\text { day). } \\
\text { HA is absorbed }{ }^{29} \text { : small MW (bacterial) HA is more } \\
\text { absorbed than high MW; small HA rejected by EFSA } \\
\text { as safe food supplement (lack of studies). } .^{.0} \\
\text { CS may or may not be absorbed (after } \\
\text { degradation). }{ }^{29}\end{array}$ \\
\hline $\begin{array}{l}\text { Therapeutic safety margin (SM) } \\
\text { (Presumed) dose in MedDev versus dose of } \\
\text { ingredients considered safe }\end{array}$ & $\begin{array}{l}\text { Not available. } \\
\text { Dose of free TA or GA equivalents in GT: } \\
\text { Oral exposure } 100 \times \text { higher than considered } \\
\text { safe in food in EU. } \\
\quad<1 / 20 \text { of acute oral } L_{50} \text { in dog. }{ }^{62} \\
\text { TA mg dose for adults in leaflet equals or } \\
\text { is higher than 'medicinal' dose of herbal } \\
\text { tannates (not recommended below } 12 \text { years) } \\
68 \text { or albumin tannate (Tannalbin) in Germany } \\
\quad \text { (use contraindicated below age of } 5 \text { years). }{ }^{67}\end{array}$ & $\begin{array}{l}\text { Not available. } \\
\text { See GT. } \\
\text { Unknown for heat-killed probiotics. }\end{array}$ & $\begin{array}{l}\text { HA (rooster), CS: high SM } \\
\text { HA dose in HACSPol > dose in food, or recognised as } \\
\text { safe as food supplement. } \\
\text { Bacterial HA: EFSA rejected as safe food } \\
\text { supplement. } \\
\text { HA and CS may stimulate growth of residual tumour } \\
\text { cells/(gut) metastasis. } \\
\text { H2-85 } \\
\text { HA (Seprafilm) contraindicated for gastrointestinal } \\
\text { sutures (more abscesses, fistulae and sepsis). } \\
\text { Pol } 407 \text { : high surfactant dose (>1 g/day) in gel; no } \\
\text { chronic oral toxicity studies. }{ }^{31} \text { Injected: renal toxicity } \\
\text { and dyslipidaemia. }{ }^{88}\end{array}$ \\
\hline $\begin{array}{l}\text { MedDev-drug interactions? } \\
\text { Known interactions for ingredients: }\end{array}$ & $\begin{array}{l}\text { Not mentioned. } \\
\text { No studies. } \\
\text { TA or derivatives (gallic acid) } \\
\text { Inhibit CYP450, other CYP and P-glycoprotein } \\
\quad\left(P \text {-gp). } .^{90-92}\right. \\
\quad \text { Bind iron, enzymes and drugs. }{ }^{67} 71-73 \\
\text { Inhibit brush border enzymes. }{ }^{5051}\end{array}$ & $\begin{array}{l}\text { Not mentioned. } \\
\text { No studies. } \\
\text { See GT. }\end{array}$ & $\begin{array}{l}\text { Not mentioned. } \\
\text { No studies. } \\
\text { Pol 407: non-ionic surfactant: } \\
\text { Can inhibit P-gp, multidrug resistance-associated } \\
\text { proteins and efflux transporters. }{ }^{94-96} \\
\quad \text { Interferes with drug, peptide and protein } \\
\text { delivery. }{ }^{8893-96}\end{array}$ \\
\hline
\end{tabular}

$\mathrm{CS}$, chondroitin sulfate; EFSA, European Food Safety Authority; HA, hyaluronic acid; MW, molecular weight.

humans. ${ }^{565-61}$ The TA dose in GT and in GTTP $\left(1 / 20\right.$ of $\mathrm{LD}_{50}$ in the $\operatorname{dog})^{62}$ surpasses doses considered safe for use as food additive in humans and animals by European Food Safety Authority (EFSA) or FDA. ${ }^{63-66}$ The adult $\mathrm{mg}$ dose of GT $(500 \mathrm{mg}, 4-6$ times/day) corresponds to the dose of Tannalbin, a medicinal tannate-(chicken) protein-complex that is only allowed for use in children from 5 years onwards in Germany. ${ }^{67}$ As herbal tannates have not been studied in children, EMA does not recommend their use below 12 years. ${ }^{68}$ In the USA, oral tannate is on the list of OTC products for which efficacy and safety is unproven $^{69}$ : 'albumin tannate/tannin albuminate', a TA complex with albumin, is no longer available, while Factmed.com (an online platform analysing FDA data) still reveals its particular AE profile: this includes anaemia and low numbers of various blood cells. ${ }^{70}$ This is in line with the potential of tannates to bind iron and other minerals, proteins and many organic compounds. ${ }^{71-74}$

The concept that TPs are safer than their living strains cannot be taken for granted. As mentioned, TPs may result in more diarrhoea and AEs, calling for well-controlled studies on GTTP. ${ }^{41} 44$ Concerns during heating include enhanced bacteriocin production (potentially $>7$ fold), ${ }^{75}$ and rapid lysis of dead bacteria on exposure to digestive fluids, ${ }^{76}$ potentially inducing effects beyond those established for viable strains. ${ }^{414}$ In the USA, TPs are only FDA approved if supported by extensive toxicity and tolerability studies. ${ }^{77} 78$

The HA origin (animal or bacterial) is undisclosed in the leaflet, while the dose is 5-20 fold the food supplement dose approved by EFSA (rooster high-MW HA). ${ }^{79}$ On request, the marketing company disclosed that the HA corresponds to low-MW HA originating from microbial fermentation by Streptococcus equi. This bacterial low-MW HA was not considered safe for oral consumption by EFSA in 2009, because of lack of information on toxicity and bioavailability. ${ }^{80}$ Current concerns with long-term HA and CS exposure relate to stimulation of cell growth of hepatic, pancreatic or residual cancer cells. ${ }^{81-85} \mathrm{HA}$ antiadhesion barrier films for gastrointestinal surgery have raised concerns, since causing more (serious) AEs versus controls. ${ }^{86}$ Seprafilm sheets (containing HA $700 \mathrm{mg}$ ) are contraindicated for gastrointestinal anastomotic sutures because of increased incidence of abscesses, fistulae and sepsis. ${ }^{87}$ Oral experience with Pol407 (surfactant) is limited to $\sim 5-6 \mathrm{mg} /$ day as excipient for delayed release formulations, yet the daily Pol407 exposure, according to the leaflet of HACSPol, surpasses $1 \mathrm{~g}$ /day. Chronic oral toxicity for Pol407 is unavailable according to recent chemical review ${ }^{31}$ and was neither provided following our request. Pol407 has been abandoned in injectables due to nephrotoxicity and AEs on lipid balance. ${ }^{88}$

Finally, none of the leaflets refers to MedDev-drug interactions although plausible: TA is known to adsorb iron, many compounds and drugs ${ }^{71-7389}$ and is an inhibitor of cytochrome P450, other enzymes and P-glycoprotein (P-gp). ${ }^{90-92} \mathrm{HA} / \mathrm{Pol} 407$ complexes enhance or delay drug absorption ${ }^{88} 93$ while Pol407 itself inhibits P-gp, multidrug resistance-associated proteins and (blood-brain barrier) efflux transporters and interferes with delivery of proteins and peptides. ${ }^{94-96}$ 


\section{DISCUSSION}

EU marketing of barrier-claiming MedDevs for repeated oral use only requires national notification, bypassing the in-depth critical expert review by medicinal authorities. Our analysis shows that compared with the standard requirements for medicines in children, this results in marketing of oral MedDevs providing extremely limited information to patients and healthcare professionals, as there is considerably less (or no) investigational clinical data available.(table 1). For GT, the lack of adequate clinical documentation at launch has already been reported. ${ }^{97-99}$ Recently, a well-controlled clinical trial did not find efficacy in childhood gastroenteritis, ${ }^{37}$ in contrast to the outcomes of prior low-quality studies. ${ }^{34-36}{ }^{40}$ For HACPol for GORD, no comparative studies comparing directly to PPIs, in children or beyond 2 weeks, could be provided by the marketeer on our request.

When compared with the standard information that should be included in leaflets for medicines according to EMA guidance, ${ }^{7}$ all three leaflets studied are deficient. Regulations permit efficacy claims to be made, unsubstantiated by good quality clinical trials. They allow unlimited use in children from birth onwards, without any well-controlled clinical data in children. Finally, data on interactions are lacking and safety issues remain unmentioned and unexplored.

Yet, these products are directly available OTC in the EU by $\mathrm{CE}$ marking and are actively promoted to health professionals and the public. Although in the small letter section of the advertisements, reference is made to the products as MedDevs, the promotional messages regarding their indication suggest that they are similar to medicines. Their medicinal image is reinforced by publications referring to them as 'Paediatric Drugs ${ }^{19}$ or among 'drug treatments'. ${ }^{100}$

The three MedDev leaflets neither mention AEs nor information on interactions. As MedDevs generate safety data postlaunch instead of prelaunch, there is a clear difference in risk assessment when compared with medicines, for which AEs are identified prior to entering the market through controlled clinical trials in sufficient numbers of patients exposed over relevant periods of treatment. Although no AEs have been published, attributable to one of the MedDevs evaluated, this is no proof of safety. As stated by the FDA: 'Once a product leaves the controlled study environment and enters general clinical use, the ability to detect the actual incidence of an $\mathrm{AE}$ can essentially be lost'. ${ }^{101}$ There are important limitations when using spontaneously reported $\mathrm{AE}$ information, including difficulties with $\mathrm{AE}$ recognition, under-reporting, biases, estimation of population exposure and report quality. ${ }^{101-103}$ Although a more stringent European vigilance programme is under development, ${ }^{104}$ the vigilance requirements itself are less stringent for MedDevs than for medicines, resulting in improper 'pharmaco'vigilance for a regularly taken oral product. According to the Belgian 'materiovigilance' instructions, reporting of AEs associated to MedDev is 'obligatory' only if there are 'serious consequences', while reporting of other AEs remains 'facultative'. ${ }^{105}$

With the new EU regulations for MedDevs (regulation EU 2017/745), ${ }^{1}$ authorities seek more stringent clinical assessment of performance (not equal to efficacy) for some MedDev classes. So far, trials were not registered at the European level (EUDRACT being only for medicines). An information platform (EUDAMED), including a database on 'Clinical Studies and Performance Studies' and a vigilance module will be launched in 2020 to exchange legal information between the Department responsible for MedDevs and the Competent Authorities in the EU Member States. ${ }^{104}$ Yet, as EMA consultation is non-binding in this legislation, no approval of the MedDevs by an independent regulatory body is required in the $\mathrm{EU}$ (in contrast to approval by the FDA in the USA), ${ }^{106-109}$ and class III even expands gastrointestinal use of MedDevs, ${ }^{1}$ these adaptations unlikely will prevent the registration of substances for oral intake as MedDevs based on a claimed barrier effect. There is neither any requirement for efficacy and safety clinical trials specific for children.

In conclusion, this analysis indicates relevant differences in the leaflets and standards used to certify MedDevs for oral use in children in the EU, when compared with medicines. We found that oral MedDevs requiring repeated ingestion to treat a medical condition (similarly as required for medicines) are hardly or not evaluated in children. This is likely because the regulatory requirements of MedDevs differ significantly from the registration standards for medicines. In our opinion, MedDev regulations need revision, excluding all substances for repeated oral intake.

Contributors SH did conceive the idea of the work and presented a first draft; all authors contributed to the acquisition, analysis or interpretation of data for the work. All authors contributed to drafting the work or revising it critically for important intellectual content, approved of the final version to be published and agree to be accountable for all aspects of the work in ensuring that questions related to the accuracy or integrity of any part of the work are appropriately investigated and resolved.

Funding The authors have not declared a specific grant for this research from any funding agency in the public, commercial or not-for-profit sectors.

Competing interests None declared.

Patient consent for publication Not required.

Provenance and peer review Not commissioned; externally peer reviewed.

Data availability statement All data relevant to the study are included in the article or uploaded as supplementary information.

\section{REFERENCES}

1 Regulation (EU) 2017/745 of the European Parliament and of the Council of 5 April 2017 on medical devices, amending Directive 2001/83/EC, regulation (EC) NO 178/2002 and regulation (EC) NO 1223/2009 and repealing Council directives 90/385/EEC and 93/42/EEC

2 European Commission. Growth (Internal Market, Industry, Entrepreneurship and SMEs) $>$ Sectors $>$ Medical devices $>$ Regulatory framework. Available: https://ec. europa.eu/growth/sectors/medical-devices/regulatory-framework_en

3 Expert.gov. Helping U.S. companies export: an introduction to medical device legislation in the European Union. Available: https://www.export.gov/article?id= An-Introduction-to-Medical-Device-Legislation-in-the-European-Union [Accessed 17 Mar 2018].

4 Huijghebaert S, Van Winckel M, De Bruyne P, et al. EU medical device legislation (CE label) opens the door to unstudied products for OTC "medical" treatment of cough, based on "barrier" claim. BVK/SBP Congress [Abstract GP05], March 8-9, 2018, BJP [Abstract GP05]

5 Van Norman GA. Drugs and devices: comparison of European and U.S. approval processes. JACC Basic Trans/ Sci 2016;1:399-412.

6 Bergsland J, Elle OJ, Fosse E. Barriers to medical device innovation. MDER 2014;7:205-9.

7 European Medicine Agency. Legal framework. Available: http://www.ema.europa.eu/ ema/index.jsp?curl=pages/about_us/general/general_content_000127.jsp\&mid= WC0b01ac0580029320

8 Nordenmalm S, Tomasi P, Pallidis C. More medicines for children: impact of the EU paediatric regulation. Arch Dis Child 2018;103:557-64.

9 Doer B, Whitman S, Walker S. Writing for medical devices compared to pharmaceuticals: an introduction. Medical Writing 2017;26:8-13.

10 Frigerio M. Getting approval for new therapeutic medical devices versus drugs: are the differences justified? European Respiratory Review 2016;25:223-6.

11 Who: medical devices: managing the mismatch. clinical evidence for medical devices: regulatory processes focussing on Europe and the United States of America. Background Paper 2010;3.

12 European Commission dG enterprise and industry. medical devices: guidance document. borderline products, drug-delivery products and medicinal devices incorporating as an integral part, an ancillary medicinal substance or an ancillary human blood derivative. EU medical device guidance MEDDEV 2 1/3 Rev 3 , 18/05/2015.

13 Wirtshaft pharma. Näse lauft, Geschäft lauft. Der Spiegel. 2018; 5: 72. 
14 NOVENTURE/THERABEL. Tasectan® leaflet. Available: http://noventure.com/sites/ default/files/tasectan_leaflet_0.pdf

15 ANGELINI. Gelenterum Duo® Descrizione. Available: https://www.farmae.it/ gelenterum-duo-12bust.html

16 Montavit Gmbh. Tasectan® DUO für Kinder. Available: https://www.farmae.it/ gelenterum-duo-12bust.html https://www.shop-apotheke.at/baby/A4615336/ tasectan-duo-250-mg-fuer-kinder.htm

17 NORGINE. ZiverelTM solution for oral use. Instructions for use. Available: https:// www.norgine.nI/wp-content/uploads/22238101-ZIVEREL-Multi-Market-Pack-IFU-P3Benelux.-signed-1-1.pdf

18 Chung K-T, Wong TY, Wei C-I, et al. Tannins and human health: a review. Crit Rev Food Sci Nutr 1998;38:421-64.

19 Mennini M, Tolone C, Frassanito A, et al. Gelatin tannate for acute childhood gastroenteritis: a randomized, single-blind controlled trial. Pediatr Drugs 2017;19:131-7.

20 Loeb H, Vandenplas Y, Würsch P, et al. Tannin-rich carob pod for the treatment of acute-onset diarrhea. J Pediatr Gastroenterol Nutr 1989;8:480-5.

21 EU patent application EP2361623 A1 (not granted). Composition comprising a polyphenol salt and corresponding use, 2011. Available: http://www.google.com/ patents/EP2361623A1?d=en

22 Okuda T, Ito H. Tannins of constant structure in medicinal and food Plants-Hydrolyzable tannins and polyphenols related to tannins. Molecules 2011;16:2191-217.

23 Serrano J, Puupponen-Pimiä R, Dauer A, et al. Tannins: current knowledge of food sources, intake, bioavailability and biological effects. Mol Nutr Food Res 2009;53 Suppl 2:S310-\$329.

24 Hrazdina G, Van Buren P, Robinson WB. Influence of the molecular size of gelatin on reaction with tannic acid. Am J Eno/ Vitic 1969:20:66-8.

25 Paaver U, Matto V, Raal A. Total tannin content in distinct Quercus robur L. galls. J Med I Plants Research 2010:4:702-5.

26 Shrestha S, Kaushik VS, Eshwarappa RSB, et al. Pharmacognostic studies of insect gall of Quercus infectoria Olivier (Fagaceae). Asian Pac J Trop Biomed 2014:4:35-9.

27 Engström MT, Karonen M, Ahern JR, et al. Chemical Structures of Plant Hydrolyzable Tannins Reveal Their in Vitro Activity against Egg Hatching and Motility of Haemonchus contortus Nematodes. J Agric Food Chem 2016:64:840-51

28 Patent W02009138843 A1. Glycosaminoglycan oral use and compositions, 2009 Available: https://patents.google.com/patent/W02009138843A1/und

29 du Souich P, Absorption duSP. Absorption, distribution and mechanism of action of SYSADOAS. Pharmacol Ther 2014;142:362-74.

30 Litwiniuk M, Krejner A, Speyrer MS, et al. Hyaluronic acid in inflammation and tissue regeneration. Wounds 2016;28:78-88.

31 BASF-Canada. Safety data sheet Pluronic F-127 NF Prill poloxamer 407. version 4 DD. 2016/03/09.

32 Devi DR, Sabdhya P, Vheda Hari BN. Poloxamer: a novel functional molecule for drug delivery and gene therapy. J Pharm Sci Res 2013;5:159-65.

33 Ocean Health Care. Tasectan $®$ product information. Available: http://www.tasectan. ie/wp-content/uploads/2012/10/Tasectan.pdf [Accessed 2 Aug 2018].

34 Reguera DF, Alvarez SL-A, Viciana RF, et al. Prospective observational study on infants and children with acute diarrhoea treated with gelatine tannate. presented as a poster in the Congress Semana de las Enfermedades Digestivas in Madrid (Spain, 2007

35 Esteban Carretero J, Durbán Reguera F, López-Argüeta Alvarez S, et al. A comparative analysis of response to vs. ORS + gelatin tannate pediatric patients with acute diarrhea. Rev Esp Enferm Dig 2009;101:41-8.

36 Allegrini A, Costantini M. Gelatine tannate for the treatment of acute diarrhoea in adults. J Gastrointest Dig Syst 2012;02.

37 Kołodziej M, Bebenek D, Konarska Z, et al. Gelatine tannate in the management of acute gastroenteritis in children: a randomised controlled trial. BMJ Open 2018;8:e020205.

38 Aloi M, Pofi F, Tolone C, et al. Gelatin tannate as treatment for acute diarrhea in children: a prospective, randomized, parallel study. Digestive and Liver Disease 2013:45.

39 ClinicalTrials.gov NCT02280759. Efficacy of gelatine tannate in treatment of acute gastroenteritis in children, 2014.

40 Çağan E, Ceylan S, Mengi Şenay, et al. Evaluation of gelatin tannate against symptoms of acute diarrhea in pediatric patients. Med Sci Monit 2017:23:2029-34

41 Taheri P, Samadi N, Ehsani MR, et al. An evaluation and partial characterization of a bacteriocin produced by Lactococcus lactis subsp lactis ST1 isolated from goat milk. Braz. J. Microbiol. 2012;43:1452-62.

42 Piqué N, Berlanga M, Miñana-Galbis D. Health benefits of heat-killed (Tyndallized) probiotics: an overview. Int J Mol Sci 2019;20:2534

43 Taverniti V, Guglielmetti S. The immunomodulatory properties of probiotic microorganisms beyond their viability (ghost probiotics: proposal of paraprobiotic concept). Genes Nutr 2011;6:261-74

44 Sanders ME, Akkermans LMA, Haller D, et al. Safety assessment of probiotics for human use. Gut Microbes 2010;1:164-85.
45 Lopetuso L, Graziani C, Guarino A, et al. Gelatin tannate and tyndallized probiotics: a novel approach for treatment of diarrhea. Eur Rev Med Pharmaco/ Sci 2017;21:873-83

46 Moré M. Clinical and experimental gastroenterology 2015. source as mentioned on line as reference to support efficacy claims (access 30/07/2018).. Available: https:// www.montavit.com/en/products/medical-devices/tasectan-duo-powder

47 Moré MI, Swidsinski A. Saccharomyces boulardii CNCM I-745 supports regeneration of the intestinal microbiota after diarrheic dysbiosis \&ndash; a review. Clin Exp Gastroenterol 2015;14:237-55.

48 Palmieri B, Merighi A, Corbascio D, et al. Fixed combination of hyaluronic acid and chondroitin-sulphate oral formulation in a randomized double blind, placebo controlled study for the treatment of symptoms in patients with non-erosive gastroesophageal reflux. Eur Rev Med Pharmacol Sci 2013;17:3272-8.

49 Savarino V, Pace F, Scarpignato C, et al. Randomised clinical trial: mucosal protection combined with acid suppression in the treatment of non-erosive reflux disease - efficacy of Esoxx, a hyaluronic acid-chondroitin sulphate based bioadhesive formulation. Aliment Pharmacol Ther 2017:45:631-42.

50 Chauhan A, Gupta S, Mahmood A. Effect of tannic acid on brush border disaccharidases in mammalian intestine. Indian J Exp Biol 2007:45:353-8.

51 Manzano S, Williamson G. Polyphenols and phenolic acids from strawberry and apple decrease glucose uptake and transport by human intestinal Caco-2 cells. Mol Nutr Food Res 2010;54:1773-80.

52 Mrowietz U, Ternowitz T, Wiedow 0 . Selective inactivation of human neutrophil elastase by synthetic tannin. Journal of Investigative Dermatology 1991;97:529-33.

53 Tamir M, Alumot E. Inhibition of digestive enzymes by condensed tannins from green and ripe carobs. J Sci Food Agric 1969;20:199-202.

54 Kiss AK, Filipek A, Żyżyńska-Granica B, et al. Effects of Penta- $O$-galloyl- $\beta$-Dglucose on Human Neutrophil Function: significant Down-Regulation of L-selectin Expression. Phytother. Res. 2013;27:986-92.

55 Marzo F, Tosar A, Santidrian S. Effect of tannic acid on the immune response of growing chickens. J Anim Sci 1990;68:3306-12.

56 Bone K, Mills S. Tannins and oligomeric procyanidins. Adverse reactions and toxicology. In: Principles of herbal pharmacology in principles and practice of Phytotherapy. 2nd edn. Modern Herbal Medicine, 2013.

57 Rashid KA, Baldwin II, Babish JG, et al. Mutagenicity tests with gallic and tannic acid in the salmonella /mammalian microsome assay. Journal of Environmental Science and Health, Part B 1985:20:153-65.

58 Brus M, Langerholc T, Škorjanc D. Effect of hydrolysable tannins on proliferation of small intestinal porcine and human enterocytes. 8th International Symposium on the Mediterranean pig, Slovenia, Ljubljana, October 10th-12th 2013;(Suppl 4):131-4.

59 Knasmuller S, Kim T-W, Ma T-H. Synergistic effect between tannic acid and x-rays detected by the Tradescantia-micronucleus assay. Mutation Research/Fundamental and Molecular Mechanisms of Mutagenesis 1992;270:31-7.

60 Rosin MP, Stich HF. Enhancing and inhibiting effects of propyl gallate on carcinogeninduced mutagenesis. J Environ Pathol Toxicol 1980;4:159-67.

61 Pubchem review 2015.

62 Boyd EM, BERECZKY K, Godi I. The acute toxicity of tannic acid administered intragastrically. Can Med Assoc J 1965:92:1292-7.

63 EFSA. Opinion of the scientific panel on food additives, Flavourings, processing AIDS and materials in contact with food (AFC) on a Request from the Commission related to flavouring group evaluation 20: benzyl alcohols, benzaldehydes, a related acetal, benzoic acids, and related esters from chemical group 23: question $\mathrm{N}^{\circ}$ EFSA-Q-2003-163. Commission regulation (EC) NO 1565/2000 of 18 July 2000The EFSA Journal, 2005. Available: http://www.efsa.eu.int/science/afc/afc_opinions/ catindex en.htm

64 EFSA- FEEDAP Panel (EFSA Panel on Additives and Products or Substances used in Animal Feed). Scientific opinion on the safety and efficacy of tannic acid when used as feed flavouring for all animal species. EFSA Journal 2014;12.

65 EFSA panel on additives and products or substances used in animal feed (FEEDAP). Opinion of the scientific panel on additives and products or substances used in animal feed (FEEDAP) on the safety and efficacy of the product Farmatan for rabbits and piglets. EFSA Journal 2005

66 FDA.3 Tannic acid. Food for human consumption. PART 184 - DIRECT FOOD SUBSTANCES AFFIRMED AS GENERALLY RECOGNIZED AS SAFE. Subpart B-Listing of Specific Substances Affirmed as GRAS. Sec. 184. Available: https://www.accessdata. fda.gov/scripts/cdrh/cfdocs/cfffr/CFRSearch.cfm?fr=184.1097

67 Tannalbin ${ }^{2}$ Rote Liste. Gebrauchsinformation. Available: http://www. patienteninfoservice.de/a-z-liste/t/tannalbinR-tabletten/ [Accessed 6 Oct 2017].

68 EMA (European Medicinal Agency). Committee on herbal medicinal products (HMPC). assessment report on Quercus robur L, Quercus petraea (Matt.) Liebl, Quercus pubescens Willd, cortex, based on article 16D (1), article 16F and article 16h of Directive 2001/83/EC as amended (traditional use). EMA/HMPC/3206/, 2009

69 FDA. CFR-Code of Federal Regulations Title 21 - Food and Drugs. Chapter I - FDA, Dept Health and Human Services, Subchapter D - Drugs for human use. Part 310 - New Drugs; subpart E - Requirements for Specific New Drugs or Devices. Sec. 310.545. Drug products containing certain active ingredients offered OTC for certain uses: (a) inadequate data to establish general recognition of safety and efficacy if the ingredients for the specified uses [\#8 Digestive Aid Drug Products]. Available: 
https://www.accessdata.fda.gov/scripts/cdrh/cfdocs/cfcfr/CFRSearch.cfm?fr=310. 545 [Accessed 15 Jan 2017].

70 Most common side effects for patients taking albumin tannate, Tannin albuminate and tannic acid (FDA. Code of Federal Regulations, Revised as of April 1, 2017; Title 21, Volume 5 - CITE: 21CFR310.545). Available: http://factmed.com

71 Afsana K, Shiga K, Ishizuka S, et al. Reducing effect of ingesting tannic acid on the absorption of iron, but not of zinc, copper and manganese by rats. Biosci Biotechnol Biochem 2004;68:584-92.

72 Lim CK, Penesyan A, Hassan KA, Loper JE, et al. Effect of tannic acid on the transcriptome of the soil bacterium Pseudomonas protegens Pf-5. Appl Environ Microbiol 2013;79:3141-5.

73 Us patent 6180666 B1 (1997). Use of gallic acid esters to increase bioavailability of orally administered pharmaceutical compounds. Available: http://www.google.com/ patents/US6180666

74 FDA. Code of Federal Regulations, Revised as of April 1, 2017; Title 21, Volume 5 CITE: 21CFR310.545.

75 Patent US6833150B1. spray-dried bacteriocin powder with anti-microbial activity. Available: https://patents.google.com/patent/US6833150

76 Drouault S, Corthier G, Ehrlich SD, et al. Survival, physiology, and lysis of Lactococcus lactis in the digestive tract. App/ Environ Microbiol 1999;65:4881-6.

77 FDA -. GRAS notices: 324 - Heat-killed Lactobacillus plantarum. Available: https:// www.accessdata.fda.gov/scripts/fdcc/?set=GRASNotices\&sort=GRN_No\&order= DESC\&startrow=1\&type=basic\&search=lactobacillus

78 Fda -. GRAS notices: inactivated Bacillus coagulans GBI-30, 6086 is generally recognized as safe for use in foods. Available: https://www.fda.gov/downloads/Food/ IngredientsPackagingLabeling/GRAS/Noticelnventory/ucm525899.pdf

79 EFSA Panel on Dietetic Products, Nutrition and Allergies (NDA); Scientific Opinion on the substantiation of health claims related to hyaluronic acid and maintenance of joints (ID 1572, 1731, 1932, 3132) pursuant to Article 13(1) of Regulation (EC) No 1924/2006 on request from the European Commission. EFSA Journal 2009;7:1266-13.

80 EFSA panel on dietetic products, nutrition and allergies (NDA); inability to assess the safety of sodium hyaluronate added for nutritional purposes as a source of sodium in food supplements and the bioavailability of sodium from this source, based on the supporting dossier. Available: https://www.efsa.europa.eu/en/efsajournal/pub/1117

81 Becker LC, Bergfeld WF, Belsito DV, et al. Cosmetic ingredient review expert panel. Andersen FA. final report of the safety assessment of hyaluronic acid, potassium hyaluronate, and sodium hyaluronate. Int J Toxicol 2009;28:5-67.

82 Cheng XB, Kohi S, Koga A, et al. Hyaluronan stimulates pancreatic cancer cell motility. Oncotarget 2016;26:4829-40.

83 Park JU, Tsuchiya T. Tumor-Promoting activity of $48 \mathrm{kDa}$ molecular mass hyaluronic acid. Materials Transactions 2002:43:3128-30.

84 Simone P, Alberto M. Caution should be used in long-term treatment with oral compounds of hyaluronic acid in patients with a history of cancer. Clin Drug Investig 2015;35:689-92.

85 Asimakopoulou AP, Theocharis AD, Tzanakakis GN, et al. The biological role of chondroitin sulfate in cancer and chondroitin-based anticancer agents. In Vivo 2008;22:385-9.

86 Berdah SV, Mariette C, Denet C, et al. A multicentre, randomised, controlled trial to assess the safety, ease of use, and reliability of hyaluronic acid/ carboxymethylcellulose powder adhesion barrier versus no barrier in colorectal laparoscopic surgery. Trials 2014;15:413.

87 SeprafilmTM adhesion barrier. official site. important safety information. Available: https://www.seprafilm.us/

88 Dumortier G, Grossiord JL, Agnely F, et al. A review of poloxamer 407 pharmaceutical and pharmacological characteristics. Pharm Res 2006;23:2709-28.
89 Daly JS, Cooney DO. Interference by Tannic Acid with the Effectiveness of Activated Charcoal in "Universal Antidote". Clin Toxicol 1978;12:515-22.

90 Ekstrand B, Rasmussen MK, Woll F, et al. In vitro gender-dependent inhibition of porcine cytochrome P450 activity by selected flavonoids and phenolic acids. BioMed Res Intern 2015

91 Kitagawa S, Nabekura T, Nakamura Y, et al. Inhibition of P-glycoprotein function by tannic acid and pentagalloylglucose. J Pharm Pharmacol 2007;59:965-9.

92 Krajka-Kuźniak V Baer-Dubowska W. The effects of tannic acid on cytochrome P450 and phase II enzymes in mouse liver and kidney. Toxicol Lett 2003;143:209-16.

93 Wong SM, Kellaway IW, Murdan S. Enhancement of the dissolution rate and oral absorption of a poorly water soluble drug by formation of surfactant-containing microparticles. Int J Pharm 2006;317:61-8.

94 Akash MSH, Rehman K, Chen S, Chen KR. Pluronic F127-based thermosensitive gels for delivery of therapeutic proteins and peptides. Polymer Reviews 2014;54:573-97.

95 Kwon MH, Yoon JN, Baek YJ, et al. Effects of poloxamer 407-induced hyperlipidemia on hepatic multidrug resistance protein 2 (MRP2/ABCC2) and the pharmacokinetics of mycophenolic acid in rats. Biopharm Drug Dispos 2016;37:352-65

$96 \mathrm{Xu} \mathrm{W}$, Ling P, Zhang T. Polymeric micelles, a promising drug delivery system to enhance bioavailability of poorly water-soluble drugs. J Drug Deliv 2013;340315.

97 Ruszczynski M, Urbanska M, Szajewska H. Gelatin tannate for treating acute gastroenteritis: a systematic review. Ann Gastroenterol 2014;27:121-4.

98 Herzog D, im Namen der S. Was meinen Sie zum Gebrauch von gelatine Tannat Zur Behandlung von akuter Diarrhöe bei Kindern? PAEDIATRICA 2013:24.

99 Guarino A, Ashkenazi S, Gendrel D, et al. European Society for pediatric gastroenterology, hepatology, and Nutrition/European Society for pediatric infectious diseases evidence-based guidelines for the management of acute gastroenteritis in children in Europe. J Pediatr Gastroenterol Nutr 2014;59:132-52

100 Savarino E, Zentilin P, Marabotto E, et al. Drugs for improving esophageal mucosa defense: where are we now and where are we going? Ann Gastroenterol 2017:30:585-91

101 Goldman SA. The clinical impact of adverse event reporting. A MedWatch continuing education article (provided as a service by the staff College, center for drug evaluation and research, food and drug administration) 1996.

102 Cheema E, Haseeb A, Khan TM, et al. Barriers to reporting of adverse drugs reactions: a cross sectional study among community pharmacists in United Kingdom. Pharm Pract 2017;15:931.

103 Pearson BR. Under-Reporting of adverse drug reactions: the need for an automated reporting system. Home / Archives / Vol 3 No 1 (2013) / Article.

104 Boumans R. Europe: development of Eudamed well on schedule. Emergo Blog, 2018. Available: https://www.emergobyul.com/blog/2018/01/europe-developmenteudamed-well-schedule [Accessed 24 Jul 2018].

105 FAMHP. Notification d'un incident de matériovigilance. Available: https://www. famhp.be/sites/default/files/downloads/Link\%201-\%20Arbre\%20d\%C3\% A9cisionnel.pdf [Accessed 23 Jul 2018].

106 KCE reports 158C. Available: https://kce.fgov.be/sites/default/files/atoms/files/kce_ 158c_innovative_high-risk_medical_devices_0.pdf

107 Mishra S. FDA, CE mark or something else?-Thinking fast and slow. Indian Heart J 2017:69:1-5.

108 Conformity assessment bodies. In. The 'Blue Guide' on the implementation of EU product rules. Official Journal of the European Union 2016, C272 - Commission Notice(2016/C 272/01), page 75 .

109 Conley D. Two Paths for Medical Device Approval: FDA vs. CE. Health Management, 2015. Available: https://healthmanagement.org/c/healthmanagement/issuearticle/ two-paths-for-medical-device-approval-fda-vs-ce 